\title{
A grafo-numeric method of determination of the operation power of the rotor of EsRc-1400 bucket wheel excavator using computer simulation in SolidWorks
}

\author{
Florin Dumitru Popescu ${ }^{1, *}$, Sorin Mihai Radu $^{1}$, Andrei Andraș ${ }^{1}$, and Ildiko Kertész (Brînaș) ${ }^{1}$ \\ ${ }^{1}$ University of Petroșani. Dept. of Mechanical, Industrial and Transports Engineering, Romania
}

\begin{abstract}
The bucket wheel excavator (BWE) is a complex continuous digging machine, used to excavate material using a layout of buckets installed on a rotor (bucket wheel), and at the same time, using the conveyor system installed on its boom, transferring this material to the main conveyor. The bucket wheel is the operating equipment, and it rotates in the vertical plane and performs (with the boom) a pivoting movement in the horizontal plane and an ascendant - descendent movement in the vertical plane. The paper presents a new grafo-numeric method of determination of the operation power of the BWE rotor, using computer simulation in SolidWorks. The aim of using virtual models for the analysis of the operation of some components of the BWE is to reduce the specific energy consumption during cutting while maintaining the installed operation power of the rotor, to increase the excavation capacity and to improve the cutting - loading system.
\end{abstract}

\section{General considerations}

The method proposed for the determination of the operation power of the rotor has been applied to EsRc-1400 model BWE [1]. This type of excavator is used in the open pit lignite mines in Oltenia.

The geometric characteristics regarding the positioning of the rotor and the rotation mechanism are presented in figure 1 where the notations used have the following meanings:

- $H_{s}$ - the height of the rotation axis of the boom as against the operating level of the excavator;

- $L_{s p}$ - the distance between the rotation axis of the boom and the rotation axis of the upper platform;

- $L_{p}$ - the pivot length of the boom;

- $H_{s p}$ - the distance between the rotation center of the rotor and the lower surface of the boom;

- $B_{r}$ - the distance between the rotation center of the rotor and the symmetry vertical plan of the boom;

\footnotetext{
* Corresponding author: fpopescu@gmail.com
} 
- $\delta$ - the angle between the longitudinal axis of the rotor and the pivoting axis of the boom.

The arm of the excavator performs in the vertical plane an ascendant and descendant movement around the rotation axis of the boom (figure 1).

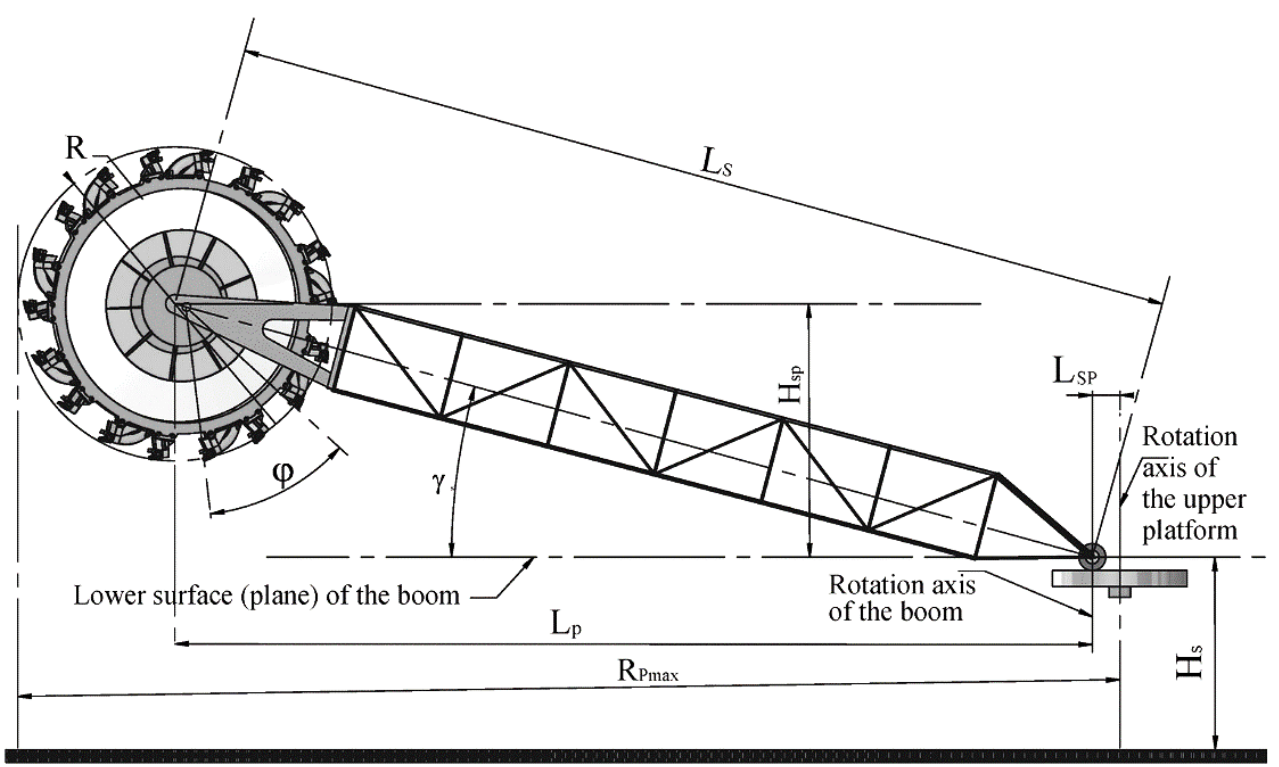

Fig.1 The geometric characteristics of the arm - rotor system, side view

Horizontally, the rotation movement occurs around the rotation axis of the upper platform with the pivoting speed $V_{p}$ (figure 2). From a technological and also energetic point of view, the planes in which the two rotations appear (ascendant - descendant and pivoting) must be vertical, respectively, horizontal. The vertical and horizontal deviation must not exceed $3,5^{\circ}-4,5^{\circ}[2]$, [3].

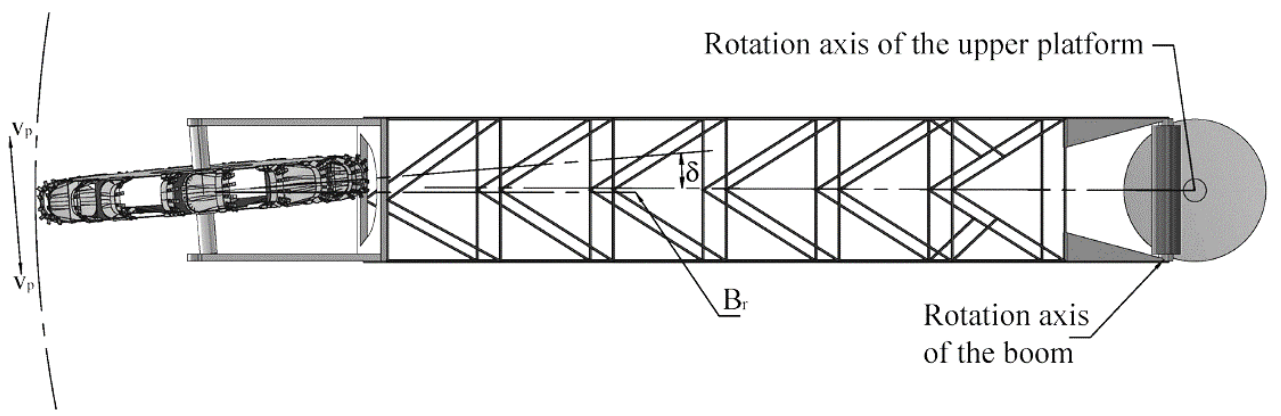

Fig.2 The geometric characteristics of the arm - rotor system, top view

Figure 3 illustrates the case of the excavation of four slices, numbered 1, 2, 3 and 4. For each of these slices, the pivoting radius is modified. For this reason, it is necessary to correlate the pivoting speed with the position of the rotor. 


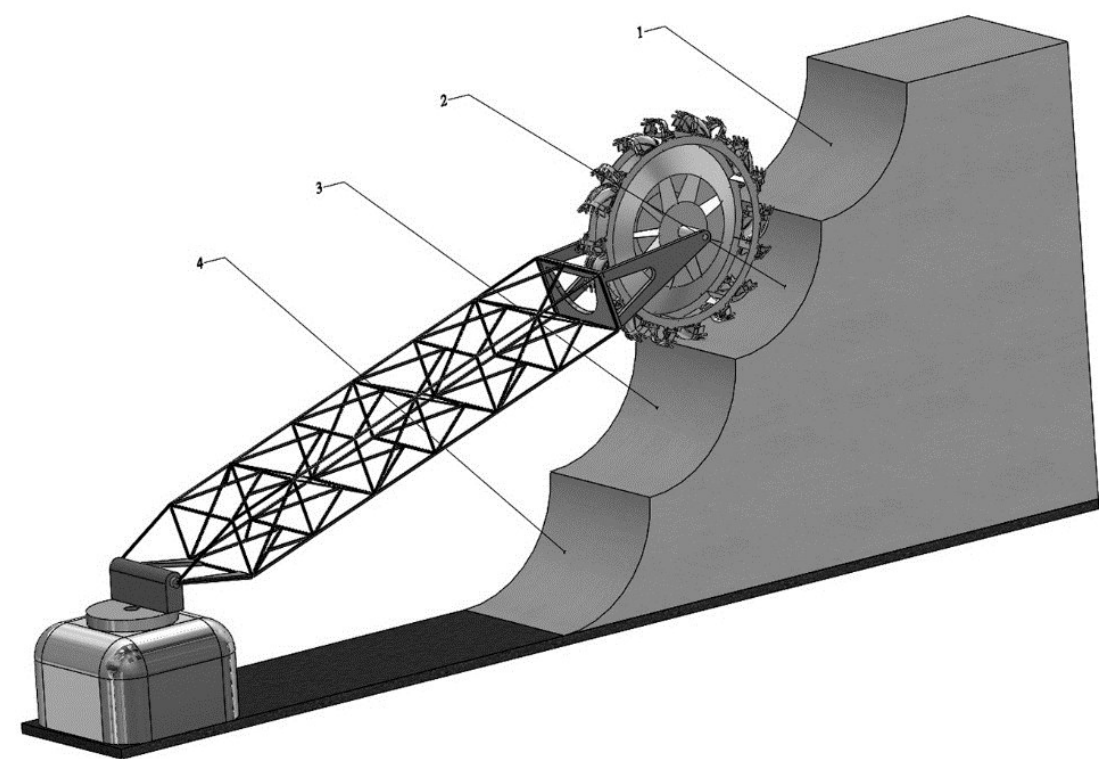

Fig.3 Excavation in four slices

\section{Definition and calculation of chipping parameters [4]}

During the rotation of the bucket wheel, the bucket cuts a sickle-shaped chip defined by points N, F and G (Figure 4).

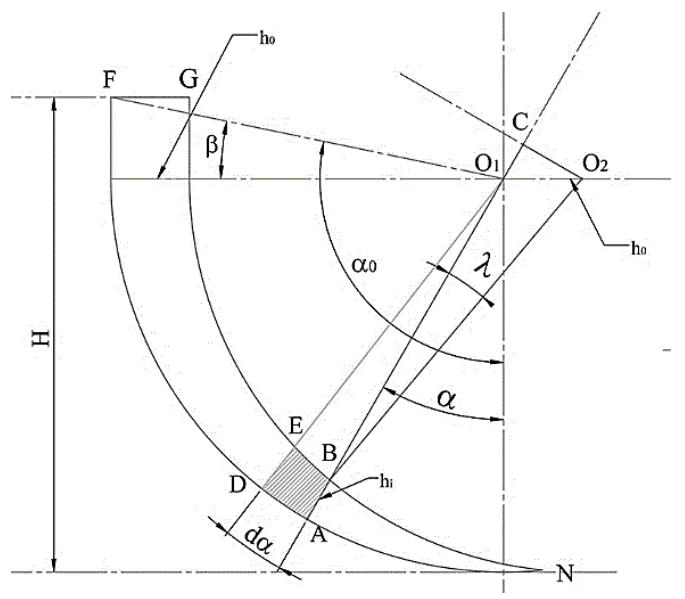

Fig.4 Description of the geometrical dimensions of the cutting of a chip

The maximum thickness of this chip is $h_{0}$ and it is equal to the length of segments $\overline{F G}$ and $\overline{\mathrm{O}_{1} \mathrm{O}_{2}}$. The geometry defined in figure 4 is based of bucket wheel radius $\mathrm{R}$ relation to segments in the equation:

$$
R=\overline{O_{1} A}=\overline{O_{2} B}
$$

For a rotation angle $\alpha$ of the bucket wheel in regard to the vertical axis we consider the thickness of the chip $t_{i}$, and we determine its size: 


$$
h_{i}=\overline{O_{1} A}-\overline{O_{1} B}=R-\overline{O_{1} B}
$$

At the same time it can be seen that:

$$
O_{1} B=B C-O_{1} C
$$

In the rectangular triangle $\triangle B C O_{2}$, taking into account the relation (2) it can be written that:

$$
\overline{B C}=\overline{O_{2} B} \cdot \cos \lambda=R \cdot \cos \lambda
$$

In the rectangular triangle $\Delta O_{1} O_{2} C$ we can see that:

$$
\overline{O_{1} C}=\overline{O_{1} O_{2}} \cdot \sin \alpha=h_{0} \cdot \sin \alpha
$$

By replacing equations (4) and (5) in equation (3) we obtain:

$$
O_{1} B=B C-O_{1} C=R \cdot \cos \gamma-h_{0} \cdot \sin \alpha
$$

In equation (2) we introduce equation (6) and we can write:

$$
h_{i}=R-R \cdot \cos \lambda+h_{0} \cdot \sin \alpha
$$

Since the angle $\lambda$ is small we can approximate (with an acceptable error) that $\cos \lambda \approx 1$ Consequently, the equation (16) will become:

$$
h_{i}=h_{0} \cdot \sin \alpha
$$

This equation expresses the variation of the chip thickness according to the rotation angle of the bucket wheel, relative to the chips maximum thickness.

For the calculation of the chip area, we consider the ABED elemental surface. We approximate the area of this surface to that of a rectangle that has a side equal to the instantaneous thickness $t_{i}$ and the other side equal to the length of arc of a circle AD. The length of the arc of a circle AD is calculated with the equations below where the elementary angle $d \alpha$ is expressed in radians:

$$
A D=R \cdot d \alpha
$$

So we can write the area of the ABED elementary surface as:

$$
S_{A B E D}=h_{i} \cdot A D=h_{i} \cdot R \cdot d \alpha=h_{0} \cdot R \cdot \sin \alpha \cdot d \alpha
$$

The total area of the chip surface is obtained by integrating the equation (10) between variation limits of the angle $\alpha$.

$$
S=\int_{0}^{\alpha_{0}} h_{0} \cdot R \cdot \sin \alpha \cdot d \alpha=\left.h_{0} \cdot R \cdot(-\cos \alpha)\right|_{0} ^{\alpha_{0}}=h_{0} \cdot R \cdot\left(1-\cos \alpha_{0}\right)
$$

In order to simulate the chip cutting process and the stresses to which the axis of the bucket wheel is subjected, it is necessary to determine the drive power of the bucket wheel. We impose a calculation magnitude that we call the effective chip thickness. It is the measure of the side of a rectangle that has an area equal to the area of the chip section determined by equation (11), and the other side is equal to the length of the arc corresponding to the maximum angle. Under these conditions, the area of the chip section in terms of effective thickness will be: 


$$
S=h_{e f} \cdot R \cdot \alpha_{0}
$$

By equating the relations (11) and (12) we obtain the expression of the effective thickness of the chip:

$$
h_{0} \cdot R \cdot\left(1-\cos \alpha_{0}\right)=h_{e f} \cdot R \cdot \alpha_{0} \Rightarrow h_{e f}=\frac{h_{0} \cdot\left(1-\cos \alpha_{0}\right)}{\alpha_{0}}
$$

The maximum excavation height will be:

$$
H=R+R \cdot \sin \beta_{0}=R \cdot\left(1+\sin \left(\alpha_{0}-90\right)\right)=R \cdot\left(1-\cos \alpha_{0}\right)
$$

The time at which this angular advance occurs between two successive cups is:

$$
T=\frac{\varphi \cdot R}{V_{t}}
$$

The chip width equation is:

$$
b=V_{p} \cdot T=\varphi \cdot R \cdot \frac{V_{p}}{V_{t}}
$$

The bulk volume of the bucket must allow the loading of all excavated rock. By denoting by $k_{a}$ the coefficient of loosening of excavated rock and $Q$ its volume, we can state that:

$$
b \cdot S \cdot k_{a}=Q
$$

Thus, we can deduce the expression of the maximum width of the excavated chip:

$$
b_{\max }=\frac{Q}{S \cdot k_{a}}=\frac{Q}{k_{a} \cdot h_{0} \cdot R \cdot\left(1-\cos \alpha_{0}\right)}
$$

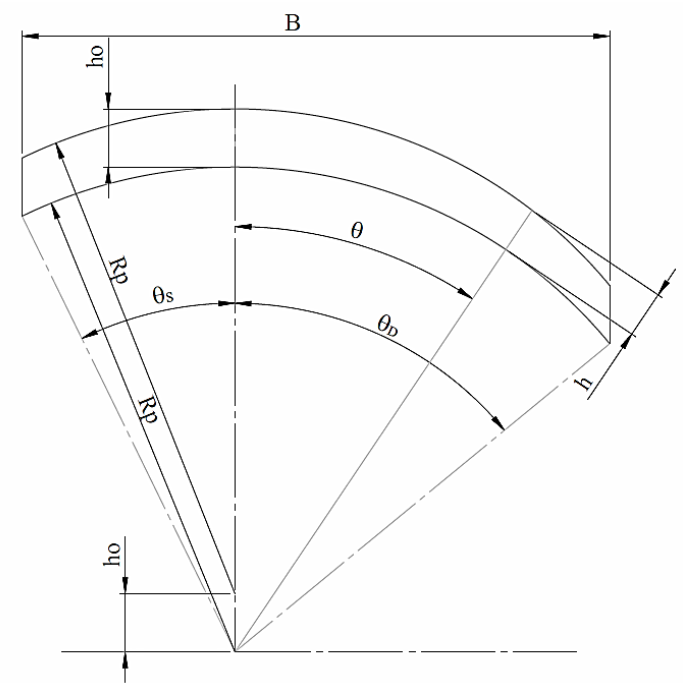

Fig.5 Geometric dimensions that characterize the volume of the excavated chip 
Figure 5 shows the geometric dimensions that characterize the volume of the excavated chip:

- $B$ the width of the extracted block;

- the position angle $\theta$ of the bucket wheel relative to the width of the excavated block.

\section{Theoretical calculation of forces and energy characteristics}

During the excavation process, the energy consumption at the level of the bucket wheel has two major components:

- the energy necessary for cutting the material to be excavated;

- the energy necessary for lifting the loose material resulted from cutting with the help of the buckets [5-6].

Between the two of the components presented above, the energy necessary for cutting the material is predominant, representing $60 \ldots 90 \%$ of the energy necessary for operating the bucket wheel.

Determining the energy and power necessary for operating the bucket wheel under certain functioning circumstances is essential for:

- the selection of a BWE from various models;

- the design of new excavators;

- the design of the new cutting - loading systems for existing BWE.

The calculus of the power necessary for cutting with rotor excavators can aim at:

- determining the dependence of the power on the parameters of the operating regime for a given excavator;

- optimizing the energetic regime by accomplishing a cutting capacity at minimum energy consumption;

- determining the dependence of the power absorbed by the cutting - loading system on the cutting capacity, respectively the pivoting speed in the working front.

For the BWEs the force characteristics refer to:

- the forces which act on the bucket represented by:

- the cutting force $F_{x}$ which operates according to a direction tangent to the trajectory of the bucket;

- the penetration force $F_{y}$ which operates according to a normal direction to the trajectory of the bucket;

- the lateral force $F_{z}$ which operates according to a bi-normal direction to the trajectory of the bucket.

- the forces which act on the rotor are represented by:

- the resultant cutting force $F_{x R}$;

- the resultant penetration force $F_{y R}$;

- the resultant lateral force $F_{z R}$.

The energetic characteristics refer to:

- the power necessary for excavation $P_{e x}$;

- the power necessary for lifting the material $P_{r}$;

- the power necessary to pivot the upper platform of the excavator, the boom and the rotor $P_{p}$.

The force and energy parameters depend on time and the characteristics of the dislocated chip. In practice, average values are employed so that we have:

According to the above information, the power necessary to drive the rotor will have the expression:

$$
P=\frac{P_{e x}+P_{r}}{\eta_{t}}
$$


where $\eta_{t}$ represents the efficiency of the engine - bucket wheel transmission [7-8].

Thus, the following results:

$$
P=\frac{1}{\Delta t \cdot \eta_{t}} Q_{t}\left[\frac{k_{u z} \cdot K_{e}}{k_{a}}+\frac{1}{\eta_{r}}\left(D-\frac{H}{2}-\frac{2}{3} h_{c}\right) \rho_{a} \cdot g\right]
$$

Where:

$Q_{t} \quad$ - the theoretical excavation capacity $\left(3280 \mathrm{~m}^{3} / \mathrm{h}\right)$;

$D \quad$ - the cutting diameter of the rotor $(11,5 \mathrm{~m})$;

$H \quad$ - the height of the bench $(7,5 \mathrm{~m})$;

$k_{u z} \quad$ - the wear degree of the teeth $(1,2)$;

$K_{e} \quad$ - the specific cutting resistance $\left(60 \mathrm{~N} / \mathrm{cm}^{2}\right)$;

$k_{a} \quad$ - loosening coefficient $(1,35)$;

$\eta_{t} \quad$ - transmission efficiency $(0,85)$;

$h_{c} \quad$ - the active height of the bucket $(0,84 \mathrm{~m})$;

$\rho_{a} \quad$ - loose rock density $\left(1,3-2 \mathrm{t} / \mathrm{m}^{3}\right)$.

After applying the relation (20), results a value of the operation power of the excavator rotor of $314 \mathrm{~kW}$.

\section{Proposal of a grafo-numeric method of determination of the operation power of the excavator bucket wheel}

For an updated version of the EsRc-1400 bucket wheel excavator, we determined the volume of material in an excavated slice. The BWE is used in the Roşiuţa open pit mine in Oltenia Basin. The cutting parameters required for the study of the working regime of this BWE are shown in Table 1. [9]

Table 1. Cutting parameters

\begin{tabular}{|c|l|c|c|c|}
\hline No. & Characteristic & Symbol & M.U. & Value \\
\hline \multirow{2}{*}{1} & Left / right pivoting angles & $\theta_{L}$ & \multirow{2}{*}{ degrees } & 42,80 \\
\cline { 5 - 5 } & & $\theta_{R}$ & & 90,00 \\
\hline 2 & Pivoting radius & $R_{p}$ & $\mathrm{~m}$ & 41,68 \\
\hline 3 & Cutting diameter of the bucket wheel & $D$ & $\mathrm{~m}$ & 11,5 \\
\hline 5 & Maximum thickness of the chip (advance step) & $h_{o}$ & $\mathrm{~m}$ & 0,6 \\
\hline
\end{tabular}

Based on these values from table 1, we have created in SolidWorks a part with a volume defined by trace of the rotor section sliding across the excavation line (Figure 6). The width of the excavation line is the width B of the extracted block as shown in Figure 5. [10]

We considered an assembly constructed of two identical parts (with geometric links between them) as defined in the previous paragraph. In figure 7 we present this assembly with the imposed distance of $0,6 \mathrm{~m}$ between the two parts, corresponding to the maximum thickness of the chip (advance step) as defined in table 1.

The volume of material in an excavated slice is obtained in SolidWorks using the "cavitation" operation applied to the two volume parts defined, as shown in figure 8. [4] 


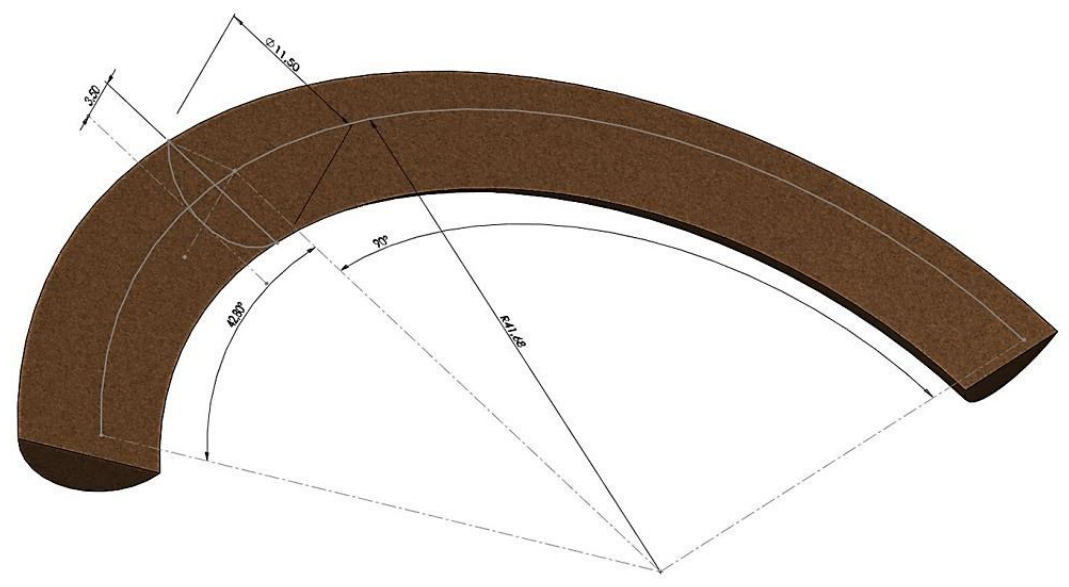

Fig. 6 Volume of the trace of the rotor during pivoting
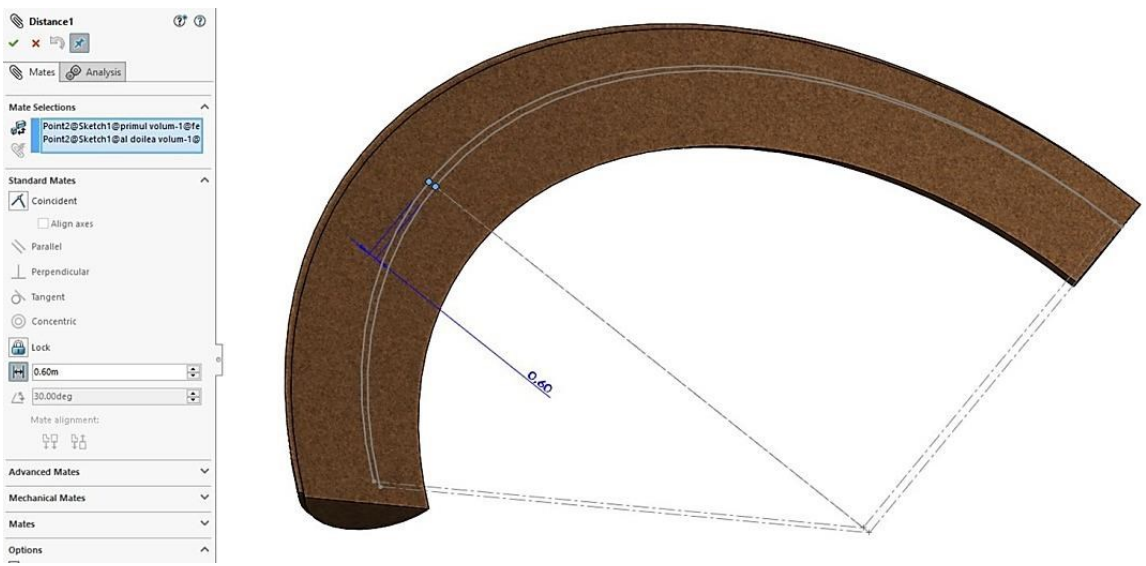

Fig. 7 Assembly of the two volumes with an imposed distance of $0.6 \mathrm{~m}$ (equal to the advance step)

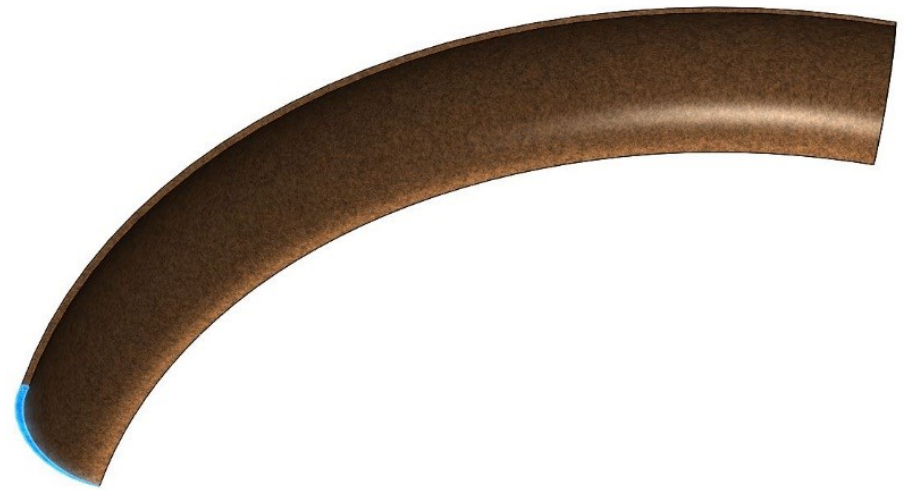

Fig. 8 Volume of an excavated slice

Using the numerical computing features of SolidWorks, using the cavitation operation for specific volumes, we determined the volume of the excavated slices for two cutting heights: 3,5 or 7,5 m respectively. The determined volumes are shown in Table 2 . 
Past research data [11 - 14] obtained by our department has highlighted that the specific energy consumption for cutting gray clays is within the range of 0,15 to $0,27 \mathrm{kWh} / \mathrm{m}^{3}$. The energy required for excavation is determined with the equation:

$$
W_{f}=V \cdot w_{s p}
$$

where:

$W_{f} \quad-$ is the total energy required to excavate one slice $(\mathrm{kWh})$;

$V \quad-$ is the volume of one slice $\left(\mathrm{m}^{3}\right)$;

$w_{s p} \quad-$ is the specific energy consumption for cutting based on past research data $\left(0,15\right.$ to $\left.0,27 \mathrm{kWh} / \mathrm{m}^{3}\right)$.

We calculated the power for the minimum, maximum and average values of the specific energy consumption during excavation. Table 2 shows the results obtained.

Table 2. Results obtained

\begin{tabular}{|c|c|c|c|c|c|c|}
\hline Nr. & $\begin{array}{l}\text { Cutting } \\
\text { height } \\
\text { (m) }\end{array}$ & $\begin{array}{c}\text { Excavated } \\
\text { volume } \\
\left(\mathbf{m}^{3}\right)\end{array}$ & $\begin{array}{c}\text { Excavation } \\
\text { time } \\
\text { (s) }\end{array}$ & $\begin{array}{c}\text { Specific } \\
\text { energy } \\
\left(\mathbf{k W h} / \mathbf{m}^{3}\right)\end{array}$ & $\begin{array}{c}\text { Energy } \\
\text { consumed } \\
(\mathbf{k J})\end{array}$ & $\begin{array}{c}\text { Excavation } \\
\text { power } \\
(\mathrm{kW})\end{array}$ \\
\hline 1 & \multirow{3}{*}{3,5} & \multirow{3}{*}{160} & \multirow{3}{*}{438} & 0,15 & 86400 & 197 \\
\hline 2 & & & & 0,21 & 129960 & 276 \\
\hline 3 & & & & 0,27 & 155520 & 355 \\
\hline 1 & \multirow{3}{*}{7,5} & \multirow{3}{*}{297} & \multirow{3}{*}{438} & 0,15 & 160380 & 366 \\
\hline 2 & & & & 0,21 & 224500 & 512 \\
\hline 3 & & & & 0,27 & 288600 & 659 \\
\hline
\end{tabular}

The excavation time corresponding to the $3,5 \mathrm{~m}$ cutting height was experimentally measured in the open pit mine, its value being 438 seconds (Table 2). For the calculation of the power corresponding to the 7,5 m cutting height, we considered the same value of the excavation time (438 seconds). It is noted that for a specific energy of cutting of 0,27 $\mathrm{kWh} / \mathrm{m}^{3}$, the required power is greater than the nominal power of the drive motor of the bucket-wheel. For these situations, it is advisable to reduce the pivoting speed of the excavator boom, which will increase the excavation time.

Considering the nominal power of the drive motor of the bucket-wheel as $P_{n}$, then the power required for excavation $P_{\text {ExMax }}$ must be less than it:

$$
P_{\text {ExMax }}<P_{n}
$$

Based on equation (22), we determine the maximum pivoting speed so that the power required for excavation does not exceed the nominal power of the bucket-wheel drive motor for certain defined cutting parameters. Thus, for the limit it can be written:

$$
P_{E x \operatorname{Max}}=\frac{W_{f}}{t_{e x}}=\frac{W_{f} \cdot v_{p \max }}{L} \Rightarrow v_{p \max }<\frac{P_{n} \cdot L}{W_{f}}
$$

where:

$t_{e x} \quad-$ is the excavation time;

$v_{p \max } \quad-$ is the maximum pivoting speed;

$L \quad-$ is the length of the slice arc;

$P_{n} \quad-$ is the nominal power of the bucket-wheel drive motor $(630 \mathrm{~kW})$.

For the cutting parameters shown in Table 1, the length of the slice arc is $L=96,61 \mathrm{~m}$. Based on equation (23), the maximum pivoting speed must not exceed 0,224 m/s. 


\section{Conclusions}

The paper proposes a way of determining the operation power of the bucket wheel of a BWE using a grafo-numeric method.

The method is based on the grafo-numerical modeling of the cutting parameters for the BWE in order to reduce the specific energy consumption during excavation while maintaining the minimum installed power of the bucket-wheel drive and increasing the excavation capacity.

We have developed a chip model resulting from the excavation process with the SolidWorks. This model is based on two identical parts to which geometric links have been imposed in order to model the shape of the bucket wheel cut for one pass. Using the cavitation operation specific to the software application, the volume of excavated rock was determined.

Based on past results of our Department research on specific energy consumption during the excavation process, we determined the power required for excavation for different cutting parameters.

For the two scenarios considered (3,5 and 7,5 m excavation heights), the calculated power with the presented method varies between 197 and $355 \mathrm{~kW}$ for the excavation height of $3,5 \mathrm{~m}$ and 366 to $659 \mathrm{~kW}$ for the excavation height of 7,5 m.

For a $3,5 \mathrm{~m}$ excavation height, the average power actually measured was $297 \mathrm{~kW}$, the difference from the value obtained using the proposed method having a deviation within permitted limits.

Because the presented method is based on numerical computational models, it has a general character, and can be applied to any type of BWE, for various rock characteristics and different cutting parameters.

\section{References}

1. $* * *$ Contract de cercetare nr.6/2002 între Universitatea din Petroşani, în calitate de prestator şi Complexul Naţional al Lignitului "Oltenia", Târgu - Jiu, în calitate de achizitor, Tema: Studiul comportării la tăiere mecanică a rocilor sterile din descoperta straturilor de lignit și a lignitului in carierele aparținând CNL Oltenia în vederea creșterii performanțelor tehnice și economice a extragerii cu ajutorul excavatoarelor cu rotor, Faza 1: Cercetări teoretice privind posibilitătile de îmbunătăţire a sistemului de tăiere - incărcare a excavatoarelor cu roată portcupe utilizate de carierele aparţinătoare C.N.L. "Oltenia", Târgu - Jiu.

2. Grecea, D.N, Teză de doctorat - Studiul posibilităților de modernizare a conducerii și monitorizării sistemelor miniere de extragere, Universitatea din Petroşani (2017)

3. Kovacs, I., Andraş, I., Nan, M.S., Popescu, F.D., Theoretical and experimental research regarding the determination of non-homogenons materials mechanical cutting characteristics, 8th WSEAS International Conference on Simulation, Modelling And Optimization, Spain (2008)

4. Kertesz (Brînaş) Ildiko, Simularea şi modelarea parametrilor de funcţionare a rotorului excavatoarelor in timpul procesului de excavare, Raport de cercetare nr.2, Petroşani (2018)

5. Kovacs, I., Nan, M.S., Andraş, I., Jula, D., Study of the working regime of the bucket wheel excavators in the conditions of Romanian open pit lignite mines, 8th WSEAS International Conference on Simulation, Modelling And Optimization, Spain (2008)

6. Kressner, M., ș.a., Cutting Resistance an Cutting Tool Design on Bucket Wheel Excavators, $8^{\mathrm{TH}}$ International Symposium, Continuous Surface Mining, Aachen (2006)

7. Raaz, V., Optimierung der maschinen- mid Verfahrenrechnischen Parameter von Schaufelradbaggem für einen abbau von harteren Materialen im Tagebau. Braunkohle in Europa: Innovationen für die Zukunfl; 1.Internationale Konferenz, in Freiberg, Tagungsband (2000)

8. Sümegi, I., Külfejtési marótárcsás kotrógépek jövesztő szerkezetének elméleti vizsgàlata és fejlesztése. Doktori értekezés, Miskolcy Egyetem (2002) 
9. Nan, M.S. Parametrii procesului de excavare la excavatoarele cu rotor. Editura Universitas, Petroşan (2007)

10. Kurowski, P.M., Engineering Analysis with SOLIDWORKS Simulation (2015)

11. Andraș, A., Fraur, F., Risteiu, M., Overview Of The Unwanted Effects Of Unmineable Rock Formations On The Mining System Of Bucket Wheel Excavator During The Excavation Process, 17th International Multidisciplinary Scientific GeoConference SGEM 2017, www.sgem.org, SGEM2017 Conference Proceedings, ISBN 978-619-7105-00-1 / ISSN 1314-2704, Vol. 17, Issue 13, 637-644 pp (2017) DOI: 10.5593/sgem2017/13/S03.081

12. Kovacs, I., Iliaş,N., Nan,M.S., Regimul de lucru al combinelor miniere, Editura Universitas, Petroşani (2000)

13. Niculescu Titu, Pasculescu Dragos, "Use of numerical simulation to study capacitive loads which is connecting to an AC power source", 15th International Multidisciplinary Scientific Geoconference, Location: Albena, Bulgaria, Informatics, Geoinformatics and Remote Sensing, vol I, 391-398 (2015)

14. Tomus, O.B., Andraș, A., Andraș, I., Study of the dependence between the cutting direction relative to stratification and the digging characteristics of lignite in oltenia coal basin (Romania), 17th International Multidisciplinary Scientific GeoConference ISBN 978-619-710500-1 / ISSN 1314-2704, vol. 17, Issue 13, 825-830, DOI: 10.5593/sgem2017/13/S03.104 (2017) 